\title{
sciendo
}

\section{Measuring a Multifaceted Concept: A high Order Confirmatory Factor Analysis Towards Internal Marketing}

\author{
Zia KHALID \\ MUST Business School, Mirpur University of Science \& Technology, Azad Jammu and Kashmir \\ softune@hotmail.com \\ Noor Ul HADI \\ College of Business Administration, Prince Mohammad Bin Fahd University, Al-Khobar, \\ Kingdom of Saudi Arabia \\ n_hadi1@yahoo.com
}

\begin{abstract}
Multi-dimensionality of internal marketing (IM) concept continuously poses a challenge for researchers because a number of measurement approaches have been used for more than a quarter of a century since its maiden empirical inception. These multiple operationalizations have augmented confusion and decision-makers are not sure which one to rely on for optimal results. Additionally, due to its evolutionary nature, research has not kept up with the pace to substantiate this evolution empirically, leaving a void for researchers to proceed for a quantitative investigation to extend its boundaries. The present research takes up this challenge and provides an empirical evidence to prove its progression. As IM is multi-faceted in nature, this research chips in two brand new dimensions, informational justice and developmental opportunities, to the IM mix, while a third dimension that has only once been studied in connection with an IM work, is also enfolded. To this end, a top-down high order confirmatory factor analysis was done to identify the underlying structure of IM dimensions. Findings of the study revealed that the hypothesized five dimensions of IM are confirmed dimensions of IM concept. This empirical stamp will embolden researchers to devise measurement scales preferably sensitive to its growing character, and capitalize on its prowess to adapt to the novelties and peculiarities of a specific industry. Moreover, this study will help in making it a more reliable tool for managers to negotiate new constraints imposed by Covid in a post-Covid world.
\end{abstract}

Keywords: Internal marketing; opportunity development; feedback; informational justice; internal market research; training

Please cite the article as follows: Khalid, Z., Hadi, N. U. (2021), "Measuring a Multifaceted concept: A high Order Confirmatory Factor Analysis Towards Internal Marketing." Management and Marketing. Challenges for the Knowledge Society, Vol. 16, No. 3, pp. 228-245, DOI: 10.2478/mmcks-2021-0014.

\section{Introduction}

Internal Marketing started in the mid-70s and gave an alternate approach to the then dominating school of thought that always showed concern about external customers. This alternative thought viewed the employee as customer, too. Berry, Hensel, and Burke (1976), Sasser and Arbeit (1976), George (1977) and Berry (1981) are greatly credited for the introduction of this concept. According to people projecting IM, it is the employee who should be the first customer of an organization. The external customer can seek satisfaction 
and value once the internal customer is also satisfied. This approach is quite old, but even writers with recent work call it evolutionary (e.g., Al-Weshah, 2019; Huang, Rundle-Thiele, \& Chen, 2019; Park \& Tran, 2020; Santa Cruz, Mero, Alcívar, \& Fernández, 2020; Svensson, 2020).

Its evolution probably owes to the fact that IM is an extraordinarily dicey concept, simple in appearance, but largely colossal to operationalize (Ahmed \& Rafiq, 2003; Qaisar \& Muhamad, 2021; Svensson, 2020). In addition to the evolutionary process IM is going through, little agreement is there on whether IM mix can be effective in influencing employees to be motivated and to work in a customer-oriented spirit (Ahmed, Rafiq, \& Saad, 2003). Svensson (2020) also points out that from theory to empirical findings, defining the internal marketing concept and what activities exactly constitute it is quite hard. IM is certainly an effective change management strategy for a great variety of context if its definitional level ambiguity is removed (Raeisi, Lingjie, \& Suhaili Binti Ramli, 2019). Yet, over the past four decades numerous attempts have been made to operationalize IM, but no consensus on the number of IM dimensions (Yildiz \& Kara, 2017) exists yet. The reason for these efforts might be that IM has the greatest effect on employee performance or customer-oriented behavior, suggesting the key role it can play in performance improvement (Imani, Foroudi, Seyyedamiri, \& Dehghani, 2020). However, its evolutionary power, which is a hallmark of IM, remains under-explored and the authors believe that practitioners can only keep it close to their minds when more and more empirical efforts are steered to expand its scope and clarify it underlying structure. To tap this abstract and nebulous concept to observable behavioral dimensions and measurable elements, we expect that universities implementing IM strategy to have five broad characteristics, i.e., internal market research, training, informational justice, developmental opportunities, and performance feedback (for details, see literature section).

Furthermore, there is practical relevance related to the dimensionality of IM in higher education institutions. According to Sahibzada et al. (2019), scale development or combining and confirming existing relevant dimensions in higher education is rare and need to be considered. Likewise, higher education is facing paramount challenges, and the only way out is to invest in academics (Altarifi, 2014) from the internal marketing perspective. Also, individuals and nations depend on the performance of their higher education institutions (Rehman \& Farooq, 2020). The globalized and liberalized world has internationalized higher education, bringing a new set of challenges to it (Akhtar \& Kalsoom, 2012). The higher education sector is facing severe competition (Alam, Ahmad, \& Hossain, 2020; Farrukh, Lee, \& Shahzad, 2019; Voon, 2006). IM is as important to higher education institutions as to any other organization in the service industry (Sahibzada, Jianfeng, Latif, \& Shafait, 2019). Universities face high competition, and IM can prove to be a differentiation tool to ensure competitive advantage (Chasanah, Hidayat, \& Mustafa, 2020). However, thrust of IM research in the last decade has been on hotels, restaurants, casinos, and financial companies (Tang, Chang, Wang, \& Lai, 2020), creating a void in the higher education sector. Thus, the evolutionary character of IM coupled with little research in higher education prompts this study. Therefore, the aim of this study is to test the proposed underlying observable behavioral dimensions and measurable elements that made IM scale in the context of higher education institutions. 


\section{Literature review}

Tansuhaj, Wong, and McCullough (1987) pioneered the IM scale with training programs, communication, rewards, motivation, and employee-customer interaction. Other than the simple statement that the literature was extensively reviewed, there was no explanation on the inclusion of dimensions or items representing these dimensions. In addition to this lacuna, the methodological rigor is also deeply missing to ascertain their status as IM companions. This is probably the prime reason for many IM scale-developers (Ahmed et al., 2003; Keller, Lynch, Ellinger, Ozment, \& Calantone, 2006; Panigyrakis \& Theodoridis, 2009; Sahibzada et al., 2019; Yildiz \& Kara, 2017) consider the scale of Foeman and Money (1995) as the first one to measure IM. Thus, Foeman and Money (1995) were the pioneer authors to present a general-purpose scale to measure IM. They introduced vision, reward and training and development, and recommended managers to consider these issues while pursing IM objectives. IM mix scale developed by Ahmed et al. (2003) in a cross-sectoral (manufacturing and service) study included 11 elements: senior leadership, strategic rewards, incentive systems, organizational structure, selection and succession, physical environment, operational/process changes, empowerment and inter-functional coordination.

The internal marketing mix scale of Keller et al. (2006) operationalized on distribution service employees also consisted of 6 dimensions: internal basic job product, internal advanced job product, internal proactive effort price, internal reactive effort price, internal place, and internal promotion. Jou, Chou, and $\mathrm{Fu}$ (2008) presented a six-factor measurement scale for IM in the service industry, including banking, medical, airline, and insurance. These factors are: empathy and consideration, upward communication, benchmarking, promotional activities, job quality and rewarding, and value and information sharing. The scale introduced for the construct of IM in retail industry by (Panigyrakis \& Theodoridis, 2009) has five dimensions: rewards, formal interaction, internal customer orientation and feedback. Bellaouaied and Gam (2011) developed the IM scale with only two dimensions: Gratitude-Empathy and Integration-support in the French banking sector.

Kameswari and Rajyalakshmi's (2012) scale of IM for the banking sector (state bank of India) contained training, work environment, wok content, superior support and colleague support. Staff recruitment, staff training, staff motivation, staff retention, job security and internal communication were the dimensions of the IM scale floated by Akroush, Abu-ElSamen, Samawi, \& Odetallah (2013) in the hospitality industry of Jordan. Altarifi (2014) validated an IM scale in the higher education sector of Jordan; having development, internal communication, internal market research, management support, vision on excellent service and performance incentives as its dimensions. Dahl and Peltier (2014) chose the health care industry of two countries, Germany and the US. The target population for their IM scale was that of nurses. Structural, physician social, nurse social, and financial bonds were the representative dimensions of their scale. For the Ghanian banking industry, Narteh and Odoom (2015) developed an IM scale having 6 dimensions: organizational culture, rewards systems, internal communication, organizational commitment and training. The IM scale of Kaur and Sharma (2015) emanates from their study of the Indian financial sector. The dimensions included: inter-functional coordination, senior leadership and vision, organizational structure and changes, internal 
communications, training and development, staffing, strategic rewards, physical environment, incentives and empowerment. Huang and Rundle-Thiele (2015) validated their scale containing training, internal market research and internal communication, simultaneously in an Asian and Western context (Taiwan and Australia) and in two sectors: tourism and higher education. Yildiz and Kara (2017) are an exception in the whole lot of IM scale developers with a unidimensional construct, calling it IM-11. The study of Sahibzada et al. (2019) introduced six elements of IM in the Chinese higher education sector: internal communication, interrelations, work support, training and development, motivation and rewards. Santa Cruz et al. (2020) studied Ecuadorian cooperatives and developed an IM-scale for this sector with the following elements: identify value exchange, work-family balance, internal communication, internal market segmentation, training, and management concern.

The field of IM can see a big progress by developing measures that will themselves provide its operationalization (Jou et al., 2008). This specific operationalization of IM with five elements thus helps in progressing the concept further in higher education institutions. Kaur and Sharma (2015) terms IM a theoretically groomed construct that lacks a valid and vibrant measurement scale. Huang and Rundle-Thiele (2015) who also developed an IM scale recommend exploring more for additional elements of IM. Bulk of management research recommends for a context specific sale; in reality however, fewer attempts are made in this regard (Sahibzada et al., 2019). Thus, their observation is also an added impetus to undertake this study. Literature also suggests that a change in organizational settings also brings a change in the elements of IM, therefore a contextual scale development becomes more inevitable (Sahibzada et al., 2019). No consensus on the number of IM dimensions (Yildiz \& Kara, 2017) exist yet. Similarly, scale development or combining and confirming existing relevant dimensions in higher education is rare and need to be considered (Sahibzada et al., 2019), since higher education is facing paramount challenges and the only way out is to invest in their academics (Altarifi, 2014) from an internal marketing perspective.

One can very effectively start survey-based IM measures to explore previous studies (Huang \& Rundle-Thiele, 2015). The current study also extensively navigated the literature on past studies and found that training and internal market research has been extensively referred as part of IM scales in recent empirical investigations (e.g., Altarifi 2014; Cruz et al., 2020; Hsieh, 2018; Huang, 2020; Huang \& Jiang, 2020; Huang \& Rundle-Thiele, 2015; Huang et al., 2019; Kadic-Maglajlic, Boso, \& Micevski, 2018; Nart, Sututemiz, Nart, \& Karatepe, 2019; Nurul Aqilah, 2018; Sahibzada et al., 2019). There is only one study (Panigyrakis \& Theodoridis, 2009) empirically attaching feedback to IM, and developmental opportunities and informational justice not at all. So, the study moves on to build a scale with a flavor of old dimensions like training and internal market research as well as new dimensions like informational justice and developmental opportunities, while performance feedback though only referred once in a research article and that too in a retail context, can also be labelled new.

Certain scholars view IM as including everything that can motivate employees and can establish cordial relations with employees (Yildiz \& Kara, 2017). The new dimensions of IM fulfill both these criteria. Developmental opportunities are a great way to motivate employees to work hard, since it carries incentives of greater competence and career growth. Having these opportunities also sends a recognition message to a person on 
his/her abilities. The informational justice means important information is shared with employees. This sharing of information also motivates them to do their job and enhances the relationship quality between employee and the elders in organization. Even in social exchange relationships, an incentive the employer offers to the employee is a continuity of career with employee (Yildiz \& Kara, 2017) and this continuity is possible only when developmental opportunities have enabled the employee to keep on growing and no key information is withheld. Ahmed et al. (2003) terms controllable elements of organization the IM mix. Whatever influential levers an organization has, they make up these IM mix elements. Based upon this definition, two new factors are chipped into the IM mix, namely Developmental opportunities and informational justice. They further call THE IM mix a set of organizationally controlled elements that can work to increase influence and motivation of employees. Since organizations can facilitate informational justice requirements of employees and their learning needs, the criterion put forward by Ahmed et al. (2003) is also fulfilled.

Since IM improves the capabilities and competencies of employees (Mishra, 2020), learning opportunities have an inherent place in the IM adobe. IM avails every reasonable opportunity to flourish well-being at work and beyond. Also, Ahmed et al. (2003) suggest IM is a competency builder. One more reason for considering them a part of IM package is due to the fact that context determines the real value of a resource in reference to a demand context. Particular context of higher education calls for a broadening of competency to meet the future demands of industry. While sticking only to monotonous and primitive tasks, the skills and knowledge gained during an academic's job in the university may very well have lost its meaning to the new needs of the market. By fulfilling employee needs, IM dimensions convey a belief of care and significance (Qaisar \& Muhamad, 2021), Since informational justice ensures the right to timely information, and explanation is not infringed while provision of developmental opportunities certifies that employee's knowledge and growth concerns are a key priority. The accession of these dimensions is again justified.

Tansuhaj, Randall, \& McCullough (1991) recommend managers to give feedback consideration in implementing IM. Keller et al (2006) also cite the work of Ballantyne (2000) to include feedback as part of IM tools. Finn, Baker, Marshall, and Anderson (1996) also point towards the inclusion of feedback in organizational mechanisms to steer employees to work on quality standards and then evaluate them on those standards. For a well-defined IM program, feedback should be one of the IM components to help employees in doing their jobs comfortably (Keller et al., 2006). Varey (1995) also terms it to be a key dimension of IM. However, the empirical-level demonstration comes from (Panigyrakis \& Theodoridis, 2009). Researchers consistently demonstrate that stronger employeeorganization ties bring positive organizational and individual outcome (Valle, 2020). This feedback can work effectively for this cause and that is why it is included here. So, the prime forces for the combination of these dimensions in the Higher Education Sector are described above. The following section goes into the literature on these IM mix elements.

\section{Developmental opportunities}

Continuous development evolves the skills of employees as changes in a certain field emerge. Abruptly meeting the changing requirements may be too difficult a task. Adaptability is thus never an overnight fix; it happens over time. Developmental 
opportunities in contrast to training are not a special activity planning a whole lot of learning activity where the services of a trainer required. It is in fact an organization-led, but employee-owned, activity. The level of learning that employees attribute to continuous learning and performing tasks that make contribution in increasing their potential is called developmental opportunities (Rego, 2009). These opportunities provide intrinsic motivation in work performance (Coetzer \& Rothmann, 2007). Developmental opportunities increase work engagement (Albrecht, Breidahl and Marty, 2018; Babic, Stinglhamber, Barbier, \& Hansez, 2019). Conradie (2011) highlights the need for developing employees to motivate them for organizational goals. It is the responsibility of organization to ensure availability of these opportunities (Rego, 2009). Van Wingerden, Derks and Bakker (2018) also call for top management's facilitating character in developmental opportunities. So, the discussion shows the commonality between training and developmental opportunities, and the role of the organization is crucial. However, Molino (2013) calls it understudied construct. The nature of higher education increases its importance many times and that is why this under-researched construct is studied here. The first hypothesis is:

\section{H1: Developmental opportunities are a confirmed dimension of IM mix.}

\section{Feedback}

Feedback ensures management and employee share similar work expectations. It clarifies employees are doing a meaningful job for organizational goals. Feedback also strengthens the communication channel between managers and employees. The specialty of this channel is that it also enhances mutual trust. Service strategy gets implemented once employees have feedback from management, according to Gronroos (1990). He further says that management can use feedback to motivate employees to be customer-focused and service-oriented. Moreover, it keeps the interest of employee alive in a job. Employees can seek direct information on their job accomplishment (Sever \& Malbašić, 2019). Where there is a learning and performance deficiency, feedback spots those deficient areas (Guarana, 2010). Those facing problems in job can resort to it for advice to be better performers (Kloutsiniotis \& Mihail, 2018). Organizations with more challenging tasks can largely simplify those tasks with feedback, as it makes these daunting tasks easier (Luthans, Youssef, \& Avolio, 2011). Since faculty involves itself in research and teaching activities that are quite demanding, the feedback can lessen its complexity. Organizations interested in coming out of closed climates should provide feedback to their subordinates. It enables employees to be more service-minded. Key aspect of a good feedback is its provision in a reasonable amount of time (George, 1990). Feedback is so important it spans over the whole organizational life (Bear, Cushenbery, London, \& Sherman, 2017). Regular feedback, at least once a month, is essential for performance (Jaiyeoba, Marandu, \& Kealesitse, 2015). So, it is hypothesized that:

H2: Feedback is a confirm dimension of IM mix.

\section{Informational justice}

Informational justice relates to the belief of an individual about receiving timely and sufficient information, and if he/she believes to have received in-time and adequate information, it will be an experience of informational justice (Campana \& Hammoud, 2015). Making a comparison between behaviors of change leaders and task and relational leaders, 
Karam et al. (2019) say change leaders show more association with this type of justice perceptions. Individuals perceiving their workplace as providing information on decisionmaking, on average experience lesser burnout than those who do not have the same perceptions (Campana \& Hammoud, 2015). All types of organizational justice uniquely contribute to endorsing fairness perceptions (Colquitt, Conlon, Wesson, Porter, \& $\mathrm{Ng}$, 2001). Ustaman, Taha, and Zakaria (2020) even go on to say it is more important than other dimensions of organizational justice. Informational justice is more objective than interpersonal justice (Zapata, Olsen, \& Martins 2013). Cheung (2013) even recommends informational justice to be a parameter for promotion of employees to leadership positions. Companies can quite successfully put informational justice into practice through the quality of explanation. Organization bent to giving quality to customers should not be blind to quality in explaining decisions (Loi, Yang, \& Diefendorff, 2009).

Although it is apparently simple, is not simple in real life, Zapata (2013) says, since informational justice involves sharing sensitive information. So, it increasingly gets complex and challenging as the sensitivity of information heightens. In spite of these issues, a critical aspect of IM is the communication style of the management towards employees (Svensson, 2020). Conduit, Matanda, and Mavondo (2014) contend that the care, support, and attention that internal customers receive from organization create a real difference. Therefore:

H3: Informational justice is a confirmed dimension of IM mix.

\section{Internal market research}

Internal market research is similar in character to the external research, except that it has a focus on the internal market of an organization, i.e., the employees. Information on external customer falls under external market research, while for internal customer it is internal market research (Huang and Rundle-Thiele, 2015). When IM declares employees as customers, it certainly means to know more and more about their perceptions and responses against the job products they are offered. An optimum way to gather this information is to choose internal market research. This research enables the organization to find out employee segments, their characteristics and needs to design and implement strategies for these identified segments (Kadic-Maglajlic et al., 2018). Altarifi (2014) says internal market research offers more opportunities to generate information. A variety of complex service encounters can also be soothed with internal market research (Nart et al., 2018). It means higher education can be a key target of this intervention. Mostly organizations are overwhelmed with the thoughts of external customers and are thus unable to consider them in marketing strategies (Szostek, 2017). Generally, this type of research is occasionally found in organizations, and even those practicing it keep it in secret cabins of HR and marketing departments (Sanchez-Hernandez \& Grayson, 2012). This practice must change for fruitful results (Sanchez-Hernandez \& Grayson, 2012). The next hypothesis is:

H4: Internal market research is a confirmed dimension of IM mix.

\section{Training}

Training is needed to prepare employees for performing functional roles and to assign them higher responsibilities (Narteh \& Odoom, 2015). After the hiring is completed, employees take part in training programs, which give them an overview of the entire 
organization so that they can find where they stand and what their importance is in overall business operations (Tanshuj, Randall, \& McCullough, 1988). Training involves spending of resources on employees. Since employees make up an organization, it has to invest in the skills of employees to improve their performance (Elnaga \& Imran, 2013).

This investment is justified because it provides a very high return, resulting in competitive advantage (Elnaga \& Imran, 2013). Shin, Kim, Kim, and Kang (2020) mention that studies show training produces more satisfied, quality-oriented, high-moral, motivated, and committed employees. They further note that trained individuals commit few mistakes and are thus more productive. As training increases satisfaction level, it compels employees to avoid organizational switching (Ocen, Francis, \& Angundaru, 2017)). It is an effort to protect an organization from a management crisis due to shortage of skills (Narteh \& Odoom, 2015). Training offers intangible benefits like improved attitude and enhanced skills, which may indicate greater service quality, satisfaction and loyalty of customers (Bansal, Mendelson, \& Sharma, 2001). They further wonder why, in spite of all these benefits, companies do not sufficiently meet the training need and invest only in case they are profitable. Therefore, we formulate the following hypothesis:

H5: Training is a confirmed dimension of IM mix.

\section{Methodology}

Four hundred questionnaires were distributed to the faculty members serving in different public sector universities of Azad Jammu \& Kashmir (AJK). A total of 341 respondents returned the questionnaires with 21 being incomplete. Thus, for the data analysis we used 320 valid responses. Having access to the population register and the generalizability consideration, simple random sampling technique was applied to collect data.

\section{Measurement}

The measurement instruments used in current study have been adapted from the works of previous researchers. Training is adapted from the scale used by Foreman \& Money (2005), Internal Market Research from Lings \& Greenley (2005), feedback from Conduit \& Movando (2001), Developmental opportunities from Bakker et al. (2010) and informational justice from Colquitt (2001).

\section{Analysis and Discussion Descriptive}

Out of the total participants, 73\% were male and remaining were female. A share of $76 \%$ was married and the remaining was single. A share of $29 \%$ hada $\mathrm{PhD}, 63 \%$ held an MS degree, and $8 \%$ had a Master's degree, while no respondent had a BS (4 years) degree. Designation-wise, 9\% were Professor, 16\% were Associate Professor, 26\% were Assistant Professor and 49\% were Lecturers. Of the total respondents, $34 \%$ lie in the age group of $30-40,46 \%$ were in the age bracket of $41-50$, and $20 \%$ were in the age bracket of 51 and above.

\section{Reliability}

The reliability and validity of the measurement model containing all constructs is evaluated following the method suggested by Hadi, Abdullah, \& Sentosa (2016b), and Hadi \& 
Muhammad (2019). Composite reliability used to evaluate internal consistency of the constructs provided satisfactory values going above the minimum requirement of 0.7 . As evident from the tables, the value for training is 0.934 , informational justice 0.920 , developmental opportunities 0.923, internal market research 0.910 , and feedback 0.788. These values endorse the internal consistency of all the constructs.

Table 1. Factor Loadings, Reliability and Validity of Constructs

\begin{tabular}{llll}
\hline Items & Loadings & Composite Reliability & Average Variance Extracted (AVE) \\
\hline TR1 & 0.954 & & \\
TR2 & 0.941 & 0.934 & 0.782 \\
TR3 & 0.934 & & \\
TR4 & 0.678 & & \\
\hline IJ1 & 0.727 & & 0.698 \\
IJ2 & 0.877 & 0.920 & \\
IJ3 & 0.855 & & \\
IJ4 & 0.828 & & \\
IJ5 & 0.881 & 0.923 & \\
\hline D01 & 0.877 & & \\
D02 & 0.860 & & \\
D03 & 0.824 & & \\
D04 & 0.902 & & \\
\hline IMR1 & 0.795 & & \\
IMR2 & 0.683 & & \\
IMR3 & 0.626 & & \\
IMR4 & 0.836 & 0.910 & \\
IMR5 & 0.874 & & \\
IMR6 & 0.835 & & \\
IMR7 & 0.713 & & \\
\hline FB1 & 0.689 & & \\
FB2 & 0.802 & 0.788 & \\
FB3 & 0.737 & & \\
\hline
\end{tabular}

Source: Authors' own research.

\section{Construct validity}

Convergent validity ensures the instrument is valid for the given construct. For reliability, Cronbach alpha along with composite reliability is used. Their values should be at or above 0.70. Fornell and Larcker (1981) recommend to look for the value of average variance extracted (AVE) to measure convergent validity. The threshold set for AVE value is greater than 0.50. All the constructs (training 0.782, informational justice 0.698, developmental opportunities 0.75 , internal market research 0.594 , feedback 0.554 ) in this study are above 0.5 .

It is clear from Table 2 that all the dimensions of Internal marketing are confirmed dimensions of IM. According to Cunningham (2008), when dimensions key variables (high order factor) are moderately to highly correlated (the correlation that exists amongst the lower-order factors), these factors are best explaining their high order factor (IM in this study). The correlation between IM and other factors like developmental opportunities, feedback, informational justice, internal market research, and training are 0.511, 0.864, $0.879,0.847$, and 0.843 respectively, signifying high correlation. Similarly, all these factors are confirmed dimensions of high order factor, as can be seen in the table below ( $p$ value for all paths originating from IM to each dimension is below the recommended threshold 
value of 0.05 ). Hence, all hypotheses (H1 to H5) are accepted. This result confirms the multifaceted concept of IM concept in Higher Education Institutions (see Figure 1 for detail).

Table 2. Path-Coefficients

\begin{tabular}{lllll}
\hline Path & B & $\begin{array}{l}\text { Standard } \\
\text { Deviation }\end{array}$ & T -Statistics & P-Values \\
\hline IM $\rightarrow$ DO & 0.511 & 0.054 & 9.476 & 0.001 \\
IM $\rightarrow$ FB & 0.864 & 0.019 & 46.427 & 0.001 \\
IM $\rightarrow$ IJ & 0.879 & 0.014 & 61.679 & 0.001 \\
IM $\rightarrow$ IMR & 0.847 & 0.022 & 38.190 & 0.001 \\
IM $\rightarrow$ TR & 0.843 & 0.021 & 40.616 & 0.001 \\
\hline
\end{tabular}

Source: Authors' own research.

IM theory has been revolving around the concept of internal customers, i.e., employees. Hence, satisfaction of external customers hinges upon satisfaction of internal customers. The message is: employees are critical in the success and failure of an organization and, therefore, they deserve as much worthy treatment as external customers. This treatment will ensure employees and organization have similar priorities on the importance of customers. Thus, a forward-looking organization is one that has a proper internal marketing system at work to create a favorable environment where such relationships could establish. In a similar suit, present research introduces a model with training, developmental opportunities, feedback, internal marker research, and informational justice as its dimensions. These IM dimensions will endure positive thoughts in employees that university does not take them for granted, but actively delivers on strategies beneficial to their cause. All this leads to a skillful human resource, which is key for university survival (Butt et al., 2020), and investing in employees bring enormous benefits to organization (Yildiz \& Kara, 2017). 


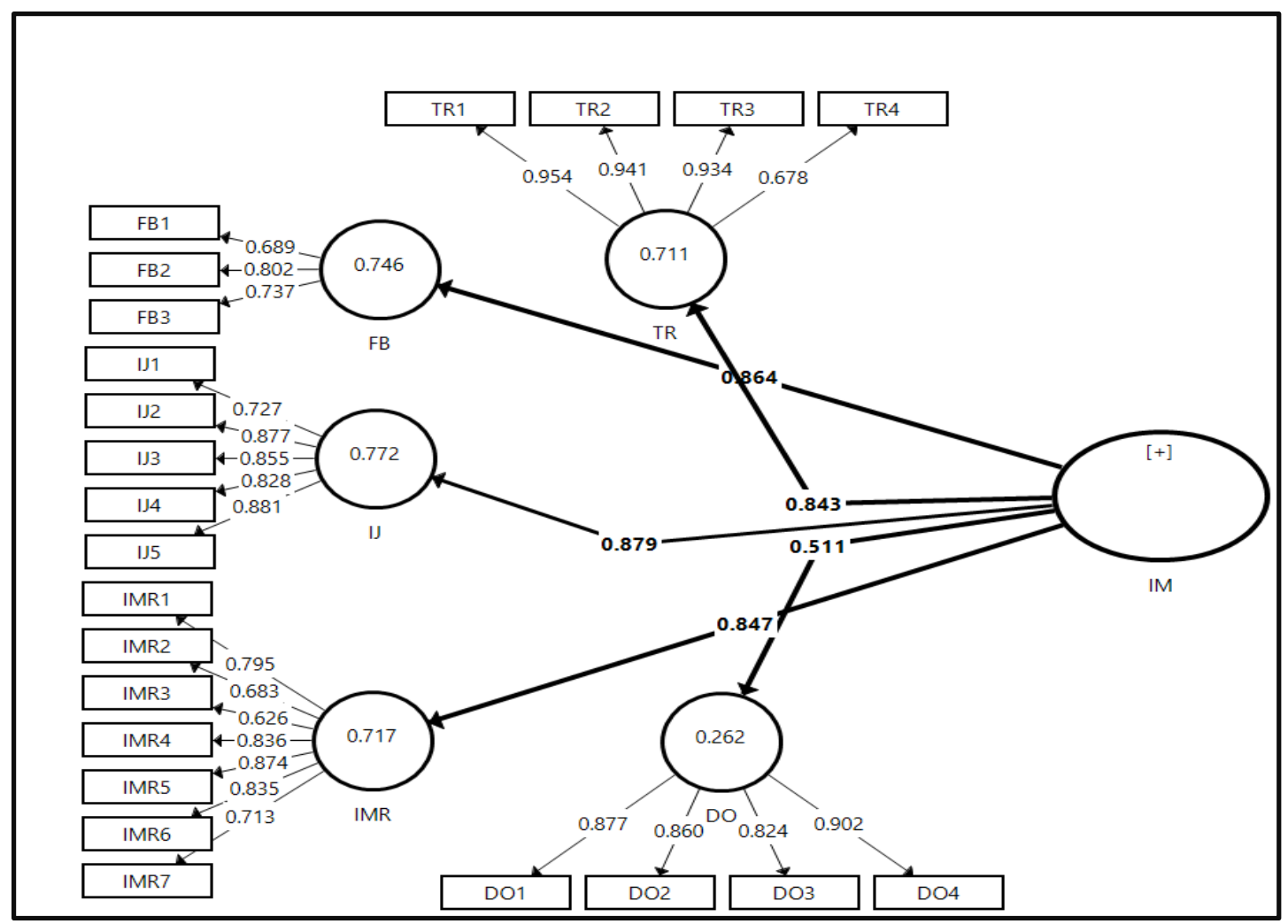

Figure 1: Tested Model

Source: Authors'

IM is also a determinant of employee concerns and their needs. In universities, certainly developmental opportunities, feedback, and informational justice represent the areas of need and concern; and the current study addresses them (Moreira Mero, Hidalgo Fernández, Loor Alcívar, \& González Santa Cruz, 2020). Since IM plans, assesses, and implements strategies on internal customers (Moreira Mero et al., 2020), this study actually reassesses IM and includes developmental opportunities and informational justice. Though IM provides competitive advantage at a global scale,it must ensure its dimensions cover expectations of employees (Moreira Mero et al., 2020). This perspective is also kept alive in the work by ensuring employee expectations regarding their competency and growth, information sharing, and a proper response towards their task attempts get covered in these dimensions. As the elements of IM can be harnessed to gain competitive advantage in a specific environment (Wedzerai et al., 2020), the present study also harnesses IM mix for higher education.

IM actually brings employee to a ready-state to deliver great services (Svensson, 2020). Voon (2006) believes that, in order to give high service quality, universities should be employee-oriented. Imani et el. (2020) ask whether organizations interested in employee performance should focus on IM. Gronroos (1985) says that internal products also consist of a work environment that keep employees motivated to meet management's demand of customer orientation. This internal product consisting of market research and informational justice truly contributes to a great environment that is transparent and committed to offer learning opportunities to its employees, and has the capacity to fulfill customer-orientation requirements of a university to effectively battle the competition. In 
developmental opportunities, the organization is a mere facilitator, and no large investment required. These opportunities equip academics to achieve technical soundness to face career challenges.

\section{Conclusion}

Probably the greatest contribution of this study, inter alia, is the induction of two new members in the family of IM (Huang 2020; Park \& Tran, 2020; Santa Cruz et al., 2020), oreven three, considering the fact that feedback has been used in only one study by Panigyrakis and Theodoridis (2009), and that too more than a decade back. These two novel members are developmental opportunities and informational justice. What differentiates this inclusion from previous efforts is they have not even been theoretically suggested to be representing IM. Although researchers have been advocating the evolutionary character of IM, this research goes a step further and joins those few people who have actually demonstrated the same (e.g., Jou et al., 2008; Keller et al. 2006). The present study has an empirically attested version of the evolution of IM. It is a tall tale to pursue the confused lot, doubtful of its precise operationalization and apt utilization. Undoubtedly, to a great extent, its findings will at least easily fall off confusion from the minds of higher educationists. Higher education is of paramount importance for developing countries. They can throw away the status-quo by adopting change, since IM scholars, as described in the introductory part, take it as a change agent and a reliable tool for competitive advantage; they can build a system solidly based on great education system. For such a system to exist and flourish, no nation can afford to be complacent with traditional strategies to carry out transformation (Afzal et al., 2019; Rehman \& Farooq, 2020). To maintain the dominance of a specific industry, organizational measures like IM are indispensable (Gwinji et al. 2020; Santa Cruz et al., 2020).

IM is evolutionary, but it has not received the due attention of researchers and is hence creating a knowledge gap. A meager advancement is made with this effort to fill it. Researchers also consider IM multidimensional, and this multidimensionality also seeks empirical endorsement. It also adds to the body of knowledge. Its uniqueness certainly owes to the inclusion of two new variables that have been suggested by Khalid and Hadi (2021), but were never tested empirically. The essence of modern-day decision making for managers and policy makers is to base their decisions on hard-core evidence. A disagreement on one operational definition of IM has been dissuading practitioners from accepting it. Results, however, are indicative that the disagreement is a strength, giving them the freedom to choose what suits them, as in the ongoing case they can opt for this model of IM to send faculty a message of being internal customers.

\section{Implications}

With the confirmation of training, performance feedback, internal market research as elements of IM and specifically the addition of two new elements of informational justice and developmental opportunities, the present research shows that anything that is valuable for employee can thrive under the umbrella of IM. The new measures do not look for any financial commitments from the university; hi-ups simply need to change their management style to integrate these practices into their working.

\section{Limitations and future directions}


Although it has great implications for various organizations, however, there are limitations. First, the population of this study is only composed of public sector universities. This limits its generalizability to other sectors. Certainty, the ground for future researchers is open to replicate this newly developed IM model, specifically in both public and private sector settings of higher education. Any organization overwhelmed with knowledge workers, like the healthcare industry and the IT industry, can also test this model in their settings, as it will surely mold employees in the desired direction. The recommendation for knowledgeworker-oriented firms is due to the fact that the present study has been conducted in a similar setting, and this synonymity of the setting increases the chances of its replicability. Secondly, developmental opportunities expand the competency horizon of people and it is an existential must for knowledge workers. Informational justice not only breaks away the chain of confusion; the targeted message also saves precious time of knowledge workers, which can be utilized for more productive activities. Thus, knowledge-worker intensive industries can primarily benefit from this research and should lead to its empirical validation. Researchers can also work on expansion of IM and may introduce some new elements in different contexts in the future. Finally, the current study measures the underlying structure of dimensions and elements that make the IM scale, and future research needs to test the impact of this IM scale on customer-oriented behavior or employee performance with mediating effects such as the organization identity.

\section{References}

Afzal, S., Arshad, M., Saleem, S., \& Farooq, O. (2019). The impact of perceived supervisor support on employees' turnover intention and task performance: Mediation of selfefficacy. Journal of Management Development, 38(5), 369-382.

Ahmed, P. K., \& Rafiq, M. (1995). The role of internal marketing in the implementation of marketing strategies. Journal of Marketing Practice: Applied Marketing Science,1(4), 32-51.

Ahmed, P. K., \& Rafiq, M. (2003). Internal marketing issues and challenges. European Journal of marketing, 37, 1177-1186.

Akroush, M. N., Abu-ElSamen, A. A., Samawi, G. A., \& Odetallah, A. L. (2013). Internal marketing and service quality in restaurants. Marketing Intelligence \& Planning, 31(4), 304-336.

Akhtar, M. M. S., \& Kalsoom, T. (2012). Issues of universities' governance in Pakistan. Journal of Elementary Education, 22(2), 81-94.

Alam, W., Ahmad, G., \& Hossain, M. M (2020). Emerging internal branding concepts: a case of higher education in Pakistan. Journal of Xi'an University of Architecture \& Technology, 12(3), 3016-3021.

Albrecht, S., Breidahl, E., \& Marty, A. (2018). Organizational resources, organizational engagement climate, and employee engagement. Career Development International, 23(1), 67-85.

Altarifi, S. (2014). Internal marketing activities in higher education. International Journal of Business and Management, 9(6), 126-138. 
Al-Weshah, G. A. (2019). Towards internal marketing practices in enhancing job engagement: Practical evidence from Jordanian hospitals. International Journal of Pharmaceutical and Healthcare Marketing, 13(1), 40-56.

Babic, A., Stinglhamber, F., Barbier, M., \& Hansez, I. (2019). Work environment and workto-family conflict: examining the mediating role of heavy work investment. Journal of Management \& Organization, 1-24.

Bansal, H. S., Mendelson, M. B., \& Sharma, B. (2001). The impact of internal marketing activities on external marketing outcomes. Journal of quality management, 6(1), 6176.

Bear, J. B., Cushenbery, L., London, M., \& Sherman, G. D. (2017). Performance feedback, power retention, and the gender gap in leadership. The Leadership Quarterly, 28(6), 721-740.

Bellaouaied, M., \& Gam, A. (2011). Internal marketing as a new alternative for the service employees' performance: an empirical study. Revue de Communication et de Marketing, 139-159.

Berry, L. L., Hensel, J. S., \& Burke, M. C. (1976). Improving retailer capability for effective consumerism response. Journal of retailing, 52(3), 3-14.

Berry, L. L. (1981). The employee as customer. Journal of retail banking, 3(1), 33-40.

Butt, A., Lodhi, R. N., \& Shahzad, M. K. (2020). Staff retention: a factor of sustainable competitive advantage in the higher education sector of Pakistan. Studies in Higher Education, 45(8), 1584-1604.

Campana, K. L., \& Hammoud, S. (2015). Incivility from patients and their families: can organisational justice protect nurses from burnout?. Journal of nursing management, 23(6), 716-725.

Chasanah, U., Hidayat, A., \& Mustafa, Z. (2020). Internal Marketing: Study of Lecturer Organizational Commitments on Private University in Indonesia. European Journal of Business and Management, 12(2), 40-57.

Cheung, M. F. (2013). The mediating role of perceived organizational support in the effects of interpersonal and informational justice on organizational citizenship behaviors. Leadership \& Organization Development Journal, 34(6), 551-572.

Coetzer, C. F., \& Rothmann, S. (2007). Job demands, job resources and work engagement of employees in a manufacturing organisation. Southern African Business Review, 11(3), 17-32.

Colquitt, J. A. (2001). On the dimensionality of organizational justice: a construct validation of a measure. Journal of applied psychology, 86(3), 386-400.

Colquitt, J. A., Conlon, D. E., Wesson, M. J., Porter, C. O., \& Ng, K. Y. (2001). Justice at the millennium: a meta-analytic review of 25 years of organizational justice research. Journal of applied psychology, 86(3), 425-45.

Conduit, J., Matanda, M. J., \& Mavondo, F. T. (2014). Balancing the act: the implications of jointly pursuing internal customer orientation and external customer orientation. Journal of Marketing Management, 30(13-14), 1320-1352.

Conduit, J., \& Mavondo, F. T. (2001). How critical is internal customer orientation to market orientation? Journal of business research, 51(1), 11-24.

Conradie, E. S. (2011). The influence of internal marketing elements on the brand awareness of car rental customers in South Africa (Doctoral dissertation, University of Johannesburg). 
Cunningham, E. (2008). A practical guide to structural equation modelling using Amos. Melbourne: Statsline.

Dahl, A. J., \& Peltier, J. W. (2014). Internal marketing and employee satisfaction and loyalty: cross-cultural scale validation in context of US and German nurses. Journal of Consumer Satisfaction, Dissatisfaction and Complaining Behavior, 27(1), 43-53.

Elnaga, A., \& Imran, A. (2013). The effect of training on employee performance. European journal of Business and Management, 5(4), 137-147.

Farrukh, M., Lee, J. W. C., \& Shahzad, I. A. (2019). Intrapreneurial behavior in higher education institutes of Pakistan. Journal of Applied Research in Higher Education, 11(2), 273-294.

Finn, D. W., Baker, J., Marshall, G. W., \& Anderson, R. (1996). Total quality management and internal customers: measuring internal service quality. Journal of Marketing Theory and Practice, 4(3), 36-51.

Foreman, S. K., \& Money, A. H. (1995). Internal marketing: concepts, measurement and application. Journal of marketing management, 11(8), 755-768.

George, W. R. (1977). Retailing of services-challenging future. Journal of Retailing, 53(3), 85-98.

Gwinji, W. A., Chiliya, N., Chuchu, T., \& Ndoro, T. (2020). An application of internal marketing for sustainable competitive advantage in Johannesburg construction firms. African Journal of Business and Economic Research, 15(1), 183-200.

Grönroos, C. (1990). Service management and marketing (Vol. 94). Lexington, MA: Lexington books.

Gronroos, C. (1985). Internal marketing-theory and practice. Services Marketing in a Changing Environment, American Marketing Association, Chicago, IL, 41(7), 42-47.

Guarana, C. L. O. (2010). The moderator effect of organizational identification on the relationship between work context and workforce engagement/burnout (Doctoral dissertation, The Ohio State University).

Hadi, N. U., Abdullah, N., \& Sentosa, I. (2016b). Making sense of mediating analysis: A marketing perspective. Review of Integrative Business and Economics Research, 5(2), 62-76.

Hadi, N. U., \& Muhammad, B. (2019). Factors influencing postgraduate students' performance: A high order top down structural equation modelling approach. Educational Sciences: Theory \& Practice, 19(2), 58-73.

Hsieh, C. M. (2018). A multilevel analysis of the service marketing triangle in theme parks. Journal of Travel \& Tourism Marketing, 35(2), 130-147.

Huang, Y. T. (2020). Internal marketing and internal customer: A review, reconceptualization, and extension. Journal of Relationship Marketing, 19(3), 165181.

Huang, Y. T., \& Jiang, Y. J. (2020). Applying Grey Relational Analysis to Evaluate Internal Marketing Practice: A Cross-Cultural Case Study in Taiwan and Mainland China Hotels. Contemporary Management Research, 16(1), 55-75.

Huang, Y. T., \& Rundle-Thiele, S. (2015). A holistic management tool for measuring internal marketing activities. Journal of Services Marketing, 29(6/7), 571-584.

Huang, Y. T., Rundle-Thiele, S., \& Chen, Y. H. (2019). Extending understanding of the internal marketing practice and employee satisfaction relationship: A budget Chinese airline empirical examination. Journal of Vacation Marketing, 25(1), 88-98. 
Imani, S., Foroudi, P., Seyyedamiri, N., \& Dehghani, N. (2020). Improving employees' performance through internal marketing and organizational learning: Mediating role of organizational innovation in an emerging market. Cogent Business \& Management, 7(1), 1-23.

Jaiyeoba, O. O., Marandu, E. E., Kealesitse, B., \& Opeda, F. O. (2015). Factors influencing attitudes and purchase intention of fashion counterfeits among Batswana college students. Journal of Business Theory and Practice, 3(2), 178-187.

Jou, J. Y., Chou, C. K., \& Fu, F. L. (2008). Development of an instrument to measure internal marketing concept. Journal of applied Management and Entrepreneurship, 13(3), 66-79.

Kadic-Maglajlic, S., Boso, N., \& Micevski, M. (2018). How internal marketing drive customer satisfaction in matured and maturing European markets?. Journal of Business Research, 86, 291-299.

Kameswari, A. V., \& Rajyalakshmi, N. (2012, January). Role of internal marketing in job satisfaction of employees in state bank of India. In Ninth AIMS International Conference on Management ,2(7), 47-55.

Kaur, J., \& Sharma, S. K. (2015). Internal marketing: Scale development and validation. Vision, 19(3), 236-247.

Keller, S. B., Lynch, D. F., Ellinger, A. E., Ozment, J., \& Calantone, R. (2006). The impact of internal marketing efforts in distribution service operations. Journal of business logistics, 27(1), 109-137.

Khalid, Z. \& Hadi, N. U. (2021). Theoretical Approach towards Internal Marketing and Customer Oriented Behavior: A Developing World Perspective. Pacific Business Review International, 13(8), 64-75.

Kloutsiniotis, P. V., \& Mihail, D. M. (2018). The link between perceived high-performance work practices, employee attitudes and service quality. Employee Relations, 40(5), 801-821.

Lings, I. N., \& Greenley, G. E. (2005). Measuring internal market orientation. Journal of service research, 7(3), 290-305.

Loi, R., Yang, J., \& Diefendorff, J. M. (2009). Four-factor justice and daily job satisfaction: a multilevel investigation. Journal of applied psychology, 94(3), 770.

Luthans, F., Youssef, C. M., \& Rawski, S. L. (2011). A tale of two paradigms: The impact of psychological capital and reinforcing feedback on problem solving and innovation. Journal of Organizational Behavior Management, 31(4), 333-350.

Moreira Mero, N., Hidalgo Fernández, A., Loor Alcívar, M. I., \& González Santa Cruz, F. (2020). Influence of internal marketing dimensions on organizational commitment: an empirical application in ecuadorian co-operativism. SAGE Open, 10(3), 1-10.

Molino, M., Ghislieri, C., \& Cortese, C. G. (2013). When work enriches family-life: The mediational role of professional development opportunities. Journal of Workplace Learning, 25(2), 98-113.

Nart, S., Sututemiz, N., Nart, S., \& Karatepe, O. M. (2019). Internal marketing practices, genuine emotions and their effects on hotel employees' customer-oriented behaviors. Journal of Human Resources in Hospitality \& Tourism, 18(1), 47-70.

Narteh, B., \& Odoom, R. (2015). Does internal marketing influence employee loyalty? Evidence from the Ghanaian banking industry. Services Marketing Quarterly, 36(2), 112-135. 
Nurul Aqilah, M. Y. (2018). Relationship between internal marketing practices, training, coworker support, emotional satisfaction and service employee commitment (Doctoral dissertation), Universiti Utara Malaysia.

Ocen, E., Francis, K., \& Angundaru, G. (2017). The role of training in building employee commitment: the mediating effect of job satisfaction. European Journal of Training and Development, 41(9), 742-757.

Panigyrakis, G. G., \& Theodoridis, P. K. (2009). Internal marketing impact on business performance in a retail context. International Journal of Retail \& Distribution Management, 37(7), 600-628.

Park, J. H., \& Tran, T. B. H. (2020). From internal marketing to customer-perceived relationship quality: evidence of Vietnamese banking firms. Total Quality Management \& Business Excellence, 31(7-8), 777-799.

Qaisar, F. S., \& Muhamad, N. (2021). Internal marketing: a review and future research agenda. Asia Pacific Business Review, 1-34.

Rafiq, M., \& Ahmed, P. K. (1993). The scope of internal marketing: defining the boundary between marketing and human resource management. Journal of marketing management, 9(3), 219-232.

Rafiq, M., \& Ahmed, P. K. (2000). Advances in the internal marketing concept: definition, synthesis and extension. Journal of services marketing. 14(6), 449-62.

Rehman, A., \& Farooq, A. (2020). Social and political dynamics of higher education in Pakistan. Pakistan Vision, 21(1), 184-198.

Rego, A. (2009). Do the opportunities for learning and personal development lead to happiness? It depends on work-family conciliation. Journal of Occupational Health Psychology, 14(3), 334.

Sahibzada, U. F., Jianfeng, C., Latif, F., \& Shafait, Z. (2019). Development and validation of a multidimensional instrument for measuring internal marketing in Chinese higher education. Journal of Enterprise Information Management, 32(3), 413-35

Sanchez-Hernandez, I., \& Grayson, D. (2012). Internal marketing for engaging employees on the corporate responsability journey. Intangible capital, 8(2), 275-307.

Santa Cruz, F. G., Mero, N. M., Alcívar, M. I. L., \& Fernández, A. H. (2020). Analysis of the Internal Marketing Dimensions in Social Economy Organizations: Study Applied to Co-operativism in Ecuador. Frontiers in Psychology, 11:580673.

Sasser, W. E., \& Arbeit, S. P. (1976). Selling jobs in the service sector. Business horizons, 19(3), 61-65.

Sever, S., \& Malbašić, I. (2019, November). Managing employee motivation with the job characteristics model. In DIEM: Dubrovnik International Economic Meeting 4(1), 5563.

Shin, M. G., Kim, Y. K., Kim, S. Y., \& Kang, D. M. (2020). Relationship between job training and subjective well-being in accordance with work Creativity, task variety, and occupation. Safety and Health at Work, 11(4), 466-478.

Svensson, E. (2020). Inside-Out: Investigating the link between internal marketing and service quality in Swedish retail (Bachelor's thesis). Open Access in DiVA:https://www.divaportal.org/smash/record.jsf?pid=diva2\%3A1440746\&dswid=9350 
Szostek, D. (2017). The Use of Marketing Research in Internal Marketing. The Methods of Measurement of Counterproductive Work Behaviours in an Organization. Annales Universitatis Mariae Curie-Skłodowska, Sectio H Oeconomia, 51(2), 245-252.

Tang, A. D., Chang, M. L., Wang, T. H., \& Lai, C. H. (2020). How to create genuine happiness for flight attendants: Effects of internal marketing and work-family interface. Journal of Air Transport Management, 87(2020), 1-9.

Tansuhaj, P., Randall, D., \& McCullough, J. (1991). Applying the internal marketing concept within large organizations: As applied to a credit union. Journal of Professional Services Marketing, 6(2), 193-202.

Tansuhaj, P., Randall, D., \& McCullough, J. (1988). A services marketing management model: integrating internal and external marketing functions. Journal of Services Marketing, 2(1), 31-38.

Tansuhaj, P., Wong, J., \& McCullough, J. (1987). Internal and external marketing: effects on consumer satisfaction in banks in Thailand. International Journal of Bank Marketing.

Valle, M., Andrews, M. C., \& Kacmar, K. M. (2020). Situational antecedents to organizational identification and the role of supervisor support. Organization Management Journal, 17(3), 153-166.

Van Wingerden, J., Derks, D., \& Bakker, A. B. (2018). Facilitating interns' performance. Career Development International, 23(4), 382-396.

Varey, R. J. (1995). Internal marketing: a review and some interdisciplinary research challenges. International Journal of Service Industry Management, 6(1), 40-63.

Voon, B. H. (2006). Linking a service-driven market orientation to service quality. Managing Service Quality, 16(6), 595-619.

Wedzerai, A. G., Chiliya, N., Chuchu, T., \& Ndoro, T. (2020). An application of internal marketing for sustainable competitive advantage in Johannesburg construction firms. African Journal of Business and Economic Research, 15(1), 183-200.

Yildiz, S. M., \& Kara, A. (2017). A unidimensional instrument for measuring internal marketing concept in the higher education sector. Quality Assurance in Education. 25(3), 343-361.

Zapata, C. P., Olsen, J. E., \& Martins, L. L. (2013). Social exchange from the supervisor's perspective: Employee trustworthiness as a predictor of interpersonal and informational justice. Organizational Behavior and Human Decision Processes, 121(1), 1-12. 